\title{
PEMBERIAN RESTITUSI SEBAGAI PERLINDUNGAN HUKUM KORBAN
}

\section{TINDAK PIDANA}

\author{
Irawan Adi Wijaya., E-mail : wanadijaya@gmail.com \\ Mahasiswa Magister Ilmu Hukum Universitas Sebelas Maret Surakarta \\ Hari Purwadi., E-mail: h_purwadie@yahoo.com \\ Dosen Magister Ilmu Hukum Universitas Sebelas Maret Surakarta
}

\begin{abstract}
Abstrack
Legal protection for victims one of them provides restitution rights, not only to certain criminal acts, but as a form of distribution of justice for victims. The existence of the Law relating to the provision of restitution to the victims has provided the rules for the protection of the victim's law, but the implementation of the restitution to the victims is still not widely applied and felt by the victims of the crime. This article will analyze the nature of restitution and formulate ideal restitution in order to fulfill justice to the victims of crime. This research is a normative legal research or literature legal research. This is based on the opinion of Peter Mahmud Marzuki that legal research is always normative. Many cases of victims of crime do not get restitution to restore the situation, both material and immaterial losses. The criminal justice has not provided certainty over the fulfillment of restitution. Therefore, special regulation regarding restitution with service model in which the victim is given service by public prosecutor to represent restitution demand so as to save cost and ease the burden of victim of crime.
\end{abstract}

Keywords: Justice; Restitution; Victim; Crime.

\begin{abstract}
Abstrak
Perlindungan hukum bagi korban salah satunya memberikan hak restitusi, tidak hanya pada tindak pidana tertentu, tetapi sebagai bentuk distribusi keadilan bagi korban. Keberadaan Undang-Undang yang terkait pemberian restitusi kepada korban telah memberikan aturan untuk perlindungan hukum korban,tetapi pelaksanaan restitusi tersebut kepada korban masih belum banyak diterapkan dan dirasakan oleh korban tindak pidana. Artikel ini hendak menganalisis bagaimana sifat pemberian restitusi dan merumuskan restitusi yang ideal agar dapat memenuhi keadilan terhadap korban tindak pidana. Penelitian ini merupakan penelitian hukum normatif atau penelitian hukum kepustakaan. Hal ini berdasarkan pendapat Peter Mahmud Marzuki bahwa penelitian hukum (legal research) selalu bersifat normatif. Banyak kasus korban tindak pidana tidak mendapatkan restitusi untuk memulihkan keadaannya, baik kerugian material maupun imaterial. Peradilan pidana belum memberikan kepastian atas pemenuhan restitusi. Sehingga diperlukan peraturan khusus mengenai pemberian restitusi dengan model pelayanan dimana korban diberikan pelayanan oleh penuntut umum guna mewakili tuntutan restitusi sehingga menghemat biaya dan meringankan beban korban tindak pidana.
\end{abstract}

Kata Kunci: Keadilan; Restitusi; Korban; Tindak Pidana. 


\section{A. Pendahuluan.}

Ganti kerugian merupakan aspek penting yang dibutuhkan untuk memulihkan keadaan seperti semula, meskipun dalam beberapa kasus kerugiaan itu tidak bisa betulbetul dipulihkan. Wirjono Prodjodikoro mengatakan bahwa pada hakikatnya, perbuatan melanggar hukum mengakibatkan suatu keganjilan dalam masyarakat berupa ketiadaan lagi suatu perimbangan dalam masyarakat (evenwichtsverstoring). Keguncangan dalam neraca perimbangan ini dengan sendirinya menimbulkan keinginan dan rasa keharusan, supaya keguncangan itu diperbaiki, artinya supaya neraca perimbangan dalam masyarakat dijadikan lurus lagi. (Andika Wijaya, Dida Peace Ananta, 2016:125-126) Penegakan hukum pidana nasional (baik KUHP dan KUHAP) harus dilaksanakan sesuai isi ketentuan hukum pidana nasional tersebut yang telah diatur secara tegas tanpa memperhatikan kedudukan dan kepentingan korban, ternyata hingga sampai sekarang hanya sebuah regularitas yang bersifat rutin namun tanpa makna ketika harus berhadapan dengan pentingnya perlindungan hukum korban kejahatan. (Andika Wijaya, Dida Peace Ananta, 2016: 30)

Peraturan-peraturan yang mengatur tentang restitusi tertuang didalam UU. No. 8 Tahun 1981, Kitab UU Hukum Pidana, PP No. 27 tahun 1983 Pelaksanaan Kitab UU Hukum Acara Pidana, UU No. 26 Tahun 2000 tentang Pengadilan HAM, PP No. 3 Tahun 2002 tentang Kompensasi dan Rehabilitasi terhadap Korban Pelanggaran HAM yang berat, UU No. 30 Tahun 2002 Komisi Pemberantasan Tindak Pidana Korupsi, UU No. 15 Tahun 2003 Penetapan Peraturan Perpu No. 1 tahun 2002 tentang Pemberantasan Tindak Pidana Terorisme, UU No. 21 tahun 2007 tentang Pemberantasan Tindak Pidana Orang. UU No. 13 Tahun 2006 Perlindungan Saksi dan Korban. Bahwa pengaturan restitusi yang terkandung didalam setiap peraturan perundang-undangan menjadi terkotak-kotak padahal ketentuan restitusi sebaiknya diatur didalam peraturan yang umum bukan bersifat khusus. Dalam KUHAP terdapat aturan dalam Pasal 98 ayat (1) yang menyatakan bahwa jika suatu perbuatan yang menjadi dasar dakwaan didalam suatu pemeriksaan perkara pidana oleh pengadilan negeri menimbulkan kerugian bagi orang lain, maka hakim ketua sidang atas permintaan orang itu dapat menetapkan untuk menggabungkan perkara gugatan ganti kerugian kepada perkara pidana itu. Tetapi dalam prosesnya peraturan KUHAP dalam menuntut ganti kerugian memiliki kekurangan yaitu dalam pengajuannya harus digabungkan dengan pemeriksaan pokok perkara pidananya dan korban harus berperan aktif untuk menuntut haknya dan harus berkoordinasi dengan penuntut umum 
untuk mengawal tuntutannya dan ganti rugi/restitusi yang diberikan hanya terbatas atas kerugian materiil tanpa bisa menuntut kerugian imateriil. Kemudian UU No. 31 tahun 2014 atas perubahan UU No.13 tahun 2006 tentang Perlindungan Saksi dan Korban telah mengatur ganti kerugian dengan tata cara tidak menggabungkan perkara pidana pokok, tetapi juga dalam UU tersebut masih memiliki kelemahan yaitu dalam Pasal 7A ayat (2) menyatakan bahwa tindak pidana sebagaimana dimaksud dalam ayat (1) ditetapkan dengan keputusan LPSK, peraturan ini malah membatasi korban tindak pidana dalam memperoleh hak restitusi.

Kompensasi merupakan ganti kerugian yang diberikan oleh Negara karena pelaku tidak mampu memberikan ganti kerugian sepenuhnya yang menjadi tanggungjawabnya. Restitusi merupakan ganti kerugian yang diberikan kepada korban atau keluarganya oleh pelaku atau pihak ketiga, dapat berupa pengembalian harta milik, pembayaran ganti kerugian untuk kehilangan atau penderitaan, atau penggantian biaya untuk tindakan tertentu. (Alvianto, R.V, Lex Crimen Vol. I/Jan-Mrt/2012) Dalam ketentuan perundangundangan khusus telah memberikan landasan bagi perlindungan korban termasuk dalam bentuk pemberian tuntutan ganti kerugian yang dilakukan oleh pelaku kepada korban, termuat dalam Undang-Undang Nomor 26 Tahun 2000 tentang Pengadilan Hak Asasi Manusia yang memberikan landasan bagi korban pelanggaran HAM berat untuk mendapat kompensasi dan restitusi Pasal 35 ayat (1) "Setiap korban pelanggaran hak asasi manusia yang berat dan atau ahli warisnya dapat memperoleh kompensasi, restitusi dan rehabilitasi”. Tetapi pelaksanaan restitusi dan kompensasi ganti kerugian tersebut kepada korban masih belum dapat diterapkan pada semua tindak pidana dan dirasakan oleh korban, banyak kasus-kasus seperti tindak pidana seksual terhadap anak dalam peradilan, korban tidak mendapatkan hak restitusi untuk memulihkan keadaannya, baik kerugian fisik maupun psikis. Pertentangan atau penolakan terhadap perlindungan hukum bagi korban masih saja terus bergulir, banyak kalangan menyatakan penyelenggaraan tersebut dalam penerapannya masih jauh dari harapan dan memerlukan pembaharuan hukum. Berdasarkan latar belakang tersebut, maka dalam artikel menganalisis tentang bagaimana pengaturan dan merumuskan pemberian restitusi yang ideal agar dapat memenuhi rasa keadilan terhadap korban. 


\section{B. Metode Penelitian}

Penelitian ini merupakan penelitian hukum normatif atau penelitian hukum kepustakaan. Hal ini berdasarkan pendapat Peter Mahmud Marzuki bahwa penelitian hukum (legal research) selalu bersifat normatif. (Mahmud Marzuki, 2014: 60) Penelitian normatif yaitu penelitian hukum yang meletakan hukum sebagai bangunan sistem norma yang dimaksud adalah tentang asas-asas, norma, kaidah dari peraturan perundangundangan, serta doktrin-doktrin. (Mukti Fajar, Yulianto Achmad, 2010:34) Bahwa jenis penelitian hukum normatif bukanlah positivis, jadi istilah penelitian hukum normatif tidak perlu karena istilah legal research selalu normatif. Dengan demikian jelas bahwa penelitian hukum selalu bersifat normatif. Tetapi pendekatan dan bahan-bahan yang digunakan harus diutarakan. (Peter Mahmud Marzuki, 2005:56)

\section{Hasil Penelitian dan Pembahasan}

\section{Peraturan terkait restitusi di Indonesia.}

Dalam perlindungan hukum bagi korban tindak pidana cenderung lebih sedikit daripada hak-hak terdakwa atau tersangka dalam sistem peradilan pidana, hak terpenting korban tindak pidana salah satunya adalah hak restitusi atau ganti rugi terhadap apa yang diterima dari tindak kejahatan oleh pelaku tindak pidana, pengaturan restitusi dalam memberikan jaminan masih dirasa kurang terdapat kepastian. Restitusi sudah diatur sebelumnya didalam KUHAP maupun Undang-Undang khusus lainnya tetapi masih banyak kekurangan dalam peraturan tersebut maka perlu dikaji bagaimana bentuk-bentuk restitusi yang sesuai untuk memberikan hak-hak korban tindak pidana. Berikut bentuk dan peraturan-peraturan yang mengatur restitusi dalam memberikan perlindungan hukum korban tindak pidana. Peraturan-peraturan tentang restitusi atau hak ganti rugi tertuang didalam Undang-Undang. No. 8 Tahun 1981 (KUHAP), Kitab Undang-Undnag Hukum Pidana (KUHP), Undang-Undang No. 8 Tahun 1999 tentang Perlindungan Konsumen, Undang-Undang No. 26 Tahun 2000 tentang Pengadilan HAM, Peraturan Pemerintah No. 3 Tahun 2002 tentang Kompensasi dan Rehabilitasi terhadap Korban Pelanggaran HAM yang berat, Undang-Undang No. 30 Tahun 2002 Komisi Pemberantasan Tindak Pidana Korupsi, Undang-Undang No. 15 Tahun 2003, Undang-Undang No. 15 tahun 2003 pengganti Undang-Undang No. 1 Tahun 2002 tentang Pemberantasan Tindak Pidana Terorisme, Undang-Undang No. 21 tahun 2007 tentang Pemberantasan Tindak Pidana Orang. Undang-Undang No. 31 tahun 2014 perubahan atas Undang-Undang No. 13 tahun 
2006 tentang Perlindungan Saksi dan Korban, Peraturan Pemerintah No. 44 tahun 2008 tentang Pemberian Kompensasi, Restitusi dan Bantuan kepada Saksi dan Korban, dan Undang-Undang No. 32 tahun 2009 tentang Perlindungan dan Pengelolaan Lingkungan Hidup.

Menurut penulis aturan-aturan mengenai restitusi belum efektif dilaksanakan dikarenakan dalam pemberian restitusi tersebut belum dapat diterapkan pada berbagai macam tindak pidana yang merugikan korban kejahatan, kemudian dalam tata cara pelaksanaanya pemberian restitusi tersebut juga belum seragam antara aturan satu sama lainnya bentuk pemberian ganti ruginya juga berbeda sifatnya. Seperti yang dikemukakan oleh Howard dan Mummers. Ada delapan syarat agar hukum dapat berlaku secara efektif. Salah satunya yaitu Undang-undang harus dirancang dengan baik, kaidah-kaidah yang mematoki harus dirumuskan dengan jelas dan dapat dipahami dengan penuh kepastian. Tanpa patokan-patokan yang jelas seperti ini, orang sulit untuk mengetahui apa yang sesungguhnya diharuskan, sehingga undang-undang tidak akan efektif. (Marcus Proyo Gunarto, 2008 : 69-70)

\section{Pengaturan terkait restitusi di Indonesia.}

Dibawah ini penulis akan menguraikan dalam bentuk tabel terhadap beberapa peraturan :

\begin{tabular}{|c|c|c|c|}
\hline No & Peraturan & Bentuk restitusi & Keterangan \\
\hline 01 & $\begin{array}{l}\text { Kitab Undang-Undang } \\
\text { Hukum Acara Pidana } \\
\text { (KUHAP) }\end{array}$ & $\begin{array}{l}\text { Berupa ganti } \\
\text { kerugian dari pelaku } \\
\text { kepada korban yang } \\
\text { bersifat materiil. }\end{array}$ & $\begin{array}{l}\text { Penggabungan perkara } \\
\text { dimana korban diwakili oleh } \\
\text { Penuntut Umum untuk } \\
\text { meminta hak ganti kerugian } \\
\text { di pengadilan. }\end{array}$ \\
\hline 02 & $\begin{array}{l}\text { Kitab Undang-Undang } \\
\text { Hukum Pidana } \\
\text { (KUHP) }\end{array}$ & $\begin{array}{l}\text { Ganti Kerugian } \\
\text { yang bersifat } \\
\text { kerugian yang riil. }\end{array}$ & $\begin{array}{l}\text { Sebagai pidana alternatif pada } \\
\text { pasal } 14 \mathrm{c} \text { ayat (1) diberikan } \\
\text { kepada pelaku berupa pidana } \\
\text { bersyarat apabila pelaku } \\
\text { memberikan ganti kerugian } \\
\text { kepada korban tindak pidana }\end{array}$ \\
\hline 03 & $\begin{array}{l}\text { Undang-Undang No. } 8 \\
\text { Tahun } 1999 \text { tentang }\end{array}$ & $\begin{array}{l}\text { Yang bentuknya } \\
\text { berupa kerugian riil }\end{array}$ & $\begin{array}{l}\text { Pada Pasal } 63 \text { huruf } \mathrm{c} . \\
\text { Pemberian restitusi sebagai }\end{array}$ \\
\hline
\end{tabular}




\begin{tabular}{|c|c|c|c|}
\hline & $\begin{array}{l}\text { perlindungan } \\
\text { konsumen }\end{array}$ & bagi korban. & bentuk pidana tambahan. \\
\hline 04 & $\begin{array}{l}\text { Undang-Undang No. } \\
26 \text { tahun } 2000 \text { tentang } \\
\text { Pengadilan HAM }\end{array}$ & $\begin{array}{l}\text { Ganti rugi/restitusi } \\
\text { bentuknya berupa: } \\
\text { a). Pengembalian } \\
\text { harta milik. } \\
\text { b). Pembayaran } \\
\text { ganti kerugian untuk } \\
\text { kehilangan atau } \\
\text { penderitaan, atau } \\
\text { c). Penggantian } \\
\text { biaya untuk } \\
\text { tindakan tertentu. }\end{array}$ & $\begin{array}{l}\text { Bahwa Korban pelanggaran } \\
\text { HAM berhak mendapatkan } \\
\text { kompensasi dan restitusi yang } \\
\text { harus tercantum dalam } \\
\text { putusan pengadilan HAM. } \\
\text { Terdapat dalam Pasal } 35 . \\
\text { Tetapi tidak diatur secara } \\
\text { jelas mekanisme penuntutan } \\
\text { hak restitusinya. }\end{array}$ \\
\hline 05 & 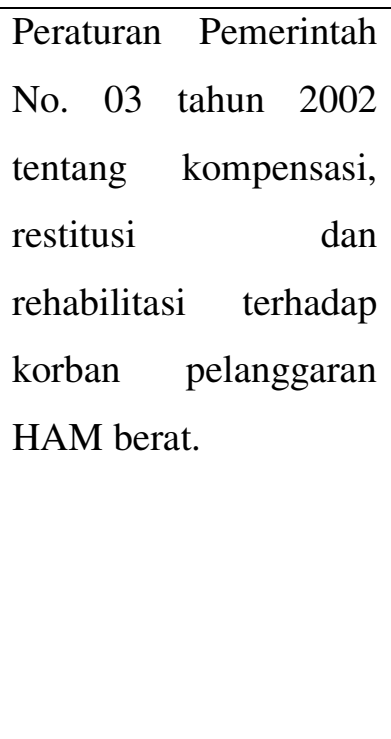 & $\begin{array}{l}\text { Bentuk ganti } \\
\text { kerugian berupa; a). } \\
\text { Pengembalian harta } \\
\text { milik. } \\
\text { b). Pembayaran } \\
\text { ganti kerugian untuk } \\
\text { kehilangan atau } \\
\text { penderitaan, atau } \\
\text { c). Penggantian } \\
\text { biaya untuk } \\
\text { tindakan tertentu. }\end{array}$ & 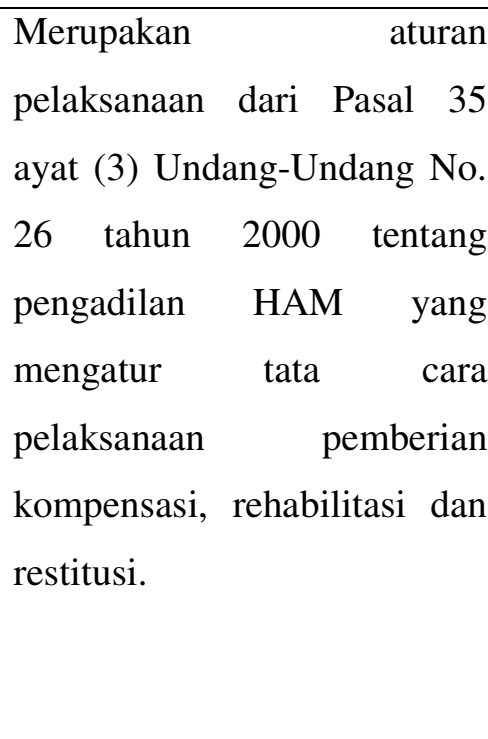 \\
\hline 06 & $\begin{array}{l}\text { Undang-Undang } \text { No. } \\
15 \quad \text { tahun } 2003 \\
\text { pengganti Nomor } \\
\text { Undang- undang No. } 1 \\
\text { Tahun 2002 tentang } \\
\text { Pemberantasan Tindak } \\
\text { Pidana Terorisme. }\end{array}$ & $\begin{array}{l}\text { Dalam pemberian } \\
\text { hak restitusi tidak } \\
\text { mengatur tentang } \\
\text { bentuk dan tata cara } \\
\text { pelaksanaannya. }\end{array}$ & $\begin{array}{l}\text { Hanya saja dalam peraturan } \\
\text { ini korban tindak pidana } \\
\text { terorisme atau ahli warisnya } \\
\text { berhak mendapatkan } \\
\text { kompensasi dan restitusi yang } \\
\text { diberikan dalam putusan } \\
\text { pengadilan. }\end{array}$ \\
\hline 07 & Undang-Undang No. & Restitusi & Dalam Pasal 7A, Permohonan \\
\hline
\end{tabular}




\begin{tabular}{|c|c|c|c|}
\hline & $\begin{array}{l}31 \text { tahun } 2014 \\
\text { perubahan atas } \\
\text { Undang-undang No. } \\
13 \text { tahun } 2006 \text { tentang } \\
\text { perlindungan saksi dan } \\
\text { korban }\end{array}$ & $\begin{array}{l}\text { bentuknya belum } \\
\text { jelas. }\end{array}$ & $\begin{array}{l}\text { restitusi } \text { oleh korban harus } \\
\text { melalui keputusan LPSK } \\
\text { untuk } \\
\text { pendampingan/tuntutan di } \\
\text { Pengadilan. }\end{array}$ \\
\hline 08 & $\begin{array}{l}\text { Peraturan Pemerintah } \\
\text { No. } 44 \text { tahun } 2008 \\
\text { tentang pemberian } \\
\text { kompensasi, restitusi } \\
\text { dan bantuan kepada } \\
\text { saksi dan korban. }\end{array}$ & $\begin{array}{l}\text { Mengatur mengenai } \\
\text { restitusi }\end{array}$ & $\begin{array}{l}\text { Mengatur tentang tata cara } \\
\text { permohonan restitusi oleh } \\
\text { korban melalui putusan LPSK } \\
\text { ke pengadilan. }\end{array}$ \\
\hline 09 & $\begin{array}{l}\text { Undang-Undang No. } \\
21 \text { tahun } 2007 \text { tentang } \\
\text { Pemberantasan Tindak } \\
\text { Pidana Perdagangan } \\
\text { Orang. }\end{array}$ & $\begin{array}{l}\text { Bentuk ganti } \\
\text { kerugian berupa; a). } \\
\text { Pengembalian harta } \\
\text { milik. } \\
\text { b). Pembayaran } \\
\text { ganti kerugian untuk } \\
\text { kehilangan atau } \\
\text { penderitaan, atau } \\
\text { c). Penggantian } \\
\text { biaya untuk } \\
\text { tindakan tertentu. }\end{array}$ & $\begin{array}{l}\text { Undang-Undang ini mengatur } \\
\text { khusus mengenai hak restitusi } \\
\text { kepada korban tindak pidana } \\
\text { perdagangan orang. }\end{array}$ \\
\hline 10 & $\begin{array}{l}\text { Undang-Undang No. } \\
32 \text { tahun } 2009 \text { tentang } \\
\text { Perlindungan dan } \\
\text { Pengelolaan } \\
\text { Lingkungan Hidup. }\end{array}$ & $\begin{array}{l}\text { Ganti kerugian } \\
\text { terhadap korban } \\
\text { lingkungan hidup }\end{array}$ & $\begin{array}{l}\text { Peraturan ini memberikan hak } \\
\text { kepada korban untuk dapat } \\
\text { menuntut dalam mekanisme } \\
\text { penggabungan perkara } \\
\text { maupun dalam tuntutan ganti } \\
\text { kerugian gugatan perdata. }\end{array}$ \\
\hline
\end{tabular}

Tabel. 01, Peraturan-peraturan terkait restitusi. 
Tabel tersebut bentuk pengaturan restitusi telah ada di berbagai peraturan perundang-undangan, tetapi tidak ada keseragamaan mengenai bentuk pemberian restitusi yang mana masih banyak kekurangan dalam pengaturannya seperti mekanisme pelaksanaannya. Sistem peradilan pidana dapat mengembangkan upaya-upaya pemulihan bagi korban pelanggaran hak asasi manusia melalui beberapa metode yang secara garis besar dibedakan menjadi dua, yakni: monetary remedies dan non-monetary remedies. Monetary remedies merupakan pemulihan yang mendayagunakan nilai materi dalam wujud uang atau fisik untuk mereparasi kerugian yang diakibatkan oleh adanya pelanggaran hak asasi manusia. Sedangkan Non Monetary Remedies adalah upaya pemulihan bagi korban yang lebih mendasarkan pada perbaikan atas kerugian yang ditimbulkan dengan langkah-langkah tertentu yang tidak dapat dipadankan dengan nilai material tertentu (seperti: permintaan maaf dari pelaku, jaminan ketidakberulangan, rehabilitasi, truth telling, hukuman bagi pelaku, atau pernyataan melalui putusan hakim (declaratory judgements). (Jurnal Hukum No. 2 Vol. 16 April 2009: 253 - 267)

Bentuk pelaksanaan restitusi yang bertujuan untuk memberi manfaat terhadap korban tindak pidana menurut teori Utilitarianisme yang merupakan teori pemikiran yang memberikan kesejahteraan bagi masyarakat secara luas, dimana untuk mengukur keadilan adalah seberapa besar manfaatnya bagi kesejahteraan manusia (human welfare). (Darji Darmodiharjo, 2012; 229) Dalam memberikan manfaat terhadap masyarakat secara luas maka penerapan ganti rugi dengan utilitarian lebih cocok melalui kompensasi dimana Negara ikut bertanggung jawab dan berempati terhadap masyarakatnya karena dianggap gagal dalam melindungi dan menertibkan masyarakatnya. Dengan memberikan kompensasi terhadap semua korban tindak pidana memang memberikan kemanfaatan terhadap korban tetapi tidak bisa menggantikan semua kerugian dan penderitaan yang dialami oleh korban dan dengan pemberian kompensasi cenderung kurang memberikan efek jera kepada pelaku kejahatan. Sebaiknya pemberian restitusi atau ganti kerugian bentuknya lebih tepat dengan pendekatan Restorative Justice (keadilan restoratif) diberikan kepada setiap individu korban tindak pidana yang mengalami kerugian baik materiil maupun imateriil, maka perlu aturan pelaksana kewajiban bagi pelaku kejahatan untuk memberikan hak-hak yang telah dirampas dari korban tindak pidana dapat disandingkan bahwa hal tersebut akan memberikan manfaat atau perlindungan bagi tiaptiap korban tindak pidana dan masyarakat luas. Bentuk pemberian restitusi dapat dilakukan baik di tingkat non-litigasi maupun litigasi, menurut penulis demi kepentingan 
korban tindak pidana maka pemberian ganti rugi yang diakibatkan oleh perbuatan tindak pidana dapat dilakukan sebelum proses peradilan/litigasi sehingga memberikan jaminan kepada korban tindak pidana dan juga memberikan manfaat atau keringanan kepada pelaku tindak pidana untuk mendapatkan keringanan hukuman karena sudah memberikan ganti rugi kepada korban tindak pidana.

Teori Restorative Justice (Keadilan Restoratif) atau dikenal dengan istilah "reparative justice" adalah suatu pendekatan keadilan yang memfokuskan kepada kebutuhan dari pada para korban, pelaku kejahatan, dan juga melibatkan peran serta masyarakat, dan tidak semata-mata memenuhi ketentuan hukum atau semata-mata penjatuhan pidana. Dalam hal ini korban juga dilibatkan di dalam proses, sementara pelaku kejahatan juga didorong untuk pertanggungjawaban atas tindakannya, yaitu dengan memperbaiki kesalahan-kesalahan yang telah mereka perbuat dengan meminta maaf, mengembalikan uang telah dicuri, atau dengan melakukan pelayanan masyarakat. Restorative justice" sebagai salah usaha untuk mencari penyelesaian konflik secara damai di luar pengadilan masih sulit diterapkan. Di Indonesia banyak hukum adat yang bisa menjadi restorative justice, namun keberadaannya tidak diakui negara atau tidak dikodifikasikan dalam hukum nasional. Hukum adat bisa menyelesaikan konflik yang muncul di masyarakat dan memberikan kepuasan pada pihak yang berkonflik. Munculnya ide restorative justice sebagai kritik atas penerapan sistem peradilan pidana dengan pemenjaraan yang dianggap tidak efektif menyelesaikan konflik sosial. Penyebabnya, pihak yang terlibat dalam konflik tersebut tidak dilibatkan dalam penyelesaian konflik. Korban tetap saja menjadi korban, pelaku yang dipenjara juga memunculkan persoalan baru bagi keluarga dan sebagainya. (Setyo Utomo: Vol. V No. 01 : 86)

Menurut Prinsip-Prinsip Dasar, sebuah "hasil restoratif” adalah kesepakatan yang dicapai sebagai hasil dari suatu proses restoratif. Perjanjian tersebut mungkin termasuk rujukan ke program-program seperti reparasi, restitusi, dan masyarakat jasa, "ditujukan untuk memenuhi kebutuhan individu dan kolektif dan tanggung jawab berbagai pihak dan mencapai reintegrasi korban dan pelaku”. Hal ini juga dapat dikombinasikan dengan langkah-langkah lain dalam kasus yang melibatkan pelanggaran serius. (UNODC, 2006: 07) Sehingga menurut penulis lebih tepat kalau di Indonesia memakai pendekatan restorative justice atau hukum adat ketimuran dan juga pemidanaan agar pelaku mendapatkan efek jera. 


\section{Proses pemberian restitusi kepada korban tindak pidana.}

Pemberian restitusi untuk korban secara umum diatur pada Undnag-Undang No. 13 tahun 2006 tentang perlindungan saksi dan korban dan Peraturan Pemerintah No. 44 tahun 2008 tentang pemberian restitusi dan bantuan kepada saksi dan korban. Dari peraturan tersebut maka korban harus aktif untuk menuntut hak restitusi kepada pelaku tindak pidana dengan memohon kepada LPSK. Prosedur ini mempunyai kelemahan yaitu tidak adanya kepastian hukum dan hak yuridis korban untuk setiap korban tindak pidana. Kemudian juga memberatkan korban secara mental dan material. Selanjutnya dalam rangka pengaturan hukum pidana terhadap korban kejahatan, secara mendasar dikenal dua model pengaturan yaitu: (Muladi, 1995:177-179)

1) Model hak-hak prosedural (The prosedural Rights Model)

2) Model pelayanan (The Services Model)

Model pertama penekanan diberikan pada dimungkinkannya si korban untuk memainkan peranan aktif di dalam proses kriminal atau di dalam jalannya proses peradilan. Dalam hal ini si korban diberi hak untuk mengadakan tuntutan pidana atau untuk membantu jaksa atau hak untuk dihadirkan dan didengar di setiap tingkatan sidang pengadilan, termasuk hak untuk diminta konsultasi oleh lembaga pemasyarakatan sebelum diberikan lepas bersyarat dan pada akhirnya hak untuk mengadakan perdamaian atau peradilan perdata.

Pada model pelayanan penekanan diletakkan pada perlunya diciptakan standarstandar baku bagi pembinaan korban kejahatan, yang dapat digunakan oleh polisi, Misalnya dalam bentuk pelayanan dalam rangka notifikasi kepada korban dan atau kejaksaan dalam rangka penanganan perkaranya, pemberian kompensaasi sebagai sanksi pidana yang bersifat restitutif dan dampak pernyataan-pernyataan korban sebelum pidana dijatuhkan. Masing-masing model tersebut ada keuntungan dan kelemahannya. Keuntungan model prosedural adalah:

1) Dapat memenuhi perasaan untuk membalas si korban maupun masyarakat;

2) Korban dapat aktif dalam proses peradilan.

Adapun kelemahan-kelemahan pada model pertama ini adalah:

1) Model ini dianggap dapat menciptakan konflik antar kepentingan umum dan kepentingan pribadi; dan

2) Kemungkinan hak-hak yang diberikan kepada korban tersebut justru dapat menimbulkan beban mental bagi yang bersangkutan dan membuka peluang untuk 
menjadikannya sebagai sasaran tindakan-tindakan yang bersifat menekan dari si pelaku tindak pidana, dan bahkan pada gilirannya dapat menjadikan sebagai korban yang kedua kalinya (risk of secondary victimization).

Sebaiknya penerapan pemberian restitusi di Indonesia menggunakan model kedua, keuntungannya adalah: model ini menghemat biaya karena dengan adanya pedoman yang baku, peradilan pidana dapat mempertimbangkan kerugian-kerugian yang diderita oleh si korban dalam rangka menentukan kompensasi bagi korban. Sedangkan kelemahannya adalah: kewajiban-kewajiban yang dibebankan pada polisi, jaksa dan pengadilan untuk selalu melakukan tindakan-tindakan tertentu kepada korban dianggap akan membebani aparat penegak hukum, karena semuanya didasarkan atas sarana dan prasarana yang sama. Hanya saja menurut Yenti Garnasih model yang bisa diterapkan di Indonesia adalah kombinasi keduanya. Kedua model itu harus disesuaikan dengan keadaan Indonesia, harus diukur sejauhmana saksi dan korban bisa terlibat dalam proses peradilan. Begitu pula tentang pemenuhan hak yang dapat diberikan kepada saksi dan korban. (www.hukumonline.com, 5-9-2017).

Pada dasarnya proses pemberian restitusi untuk korban tindak pidana sudah diatur dalam KUHAP, Undang-Undang Perlindungan Saksi dan Korban, dan aturan pelaksananya juga telah memberikan jalan aturan bagi korban tindak pidana untuk mendapatkan ganti kerugian yang berupa restitusi. Akan tetapi, aturan-aturan tersebut memiliki sejumlah masalah dalam penerapannya, antara lain:

1) Terbatasnya jenis dan jumlah kerugian yang dapat dimohonkan oleh korban tindak pidana apabila menggunakan model penggabungan gugatan ganti kerugian yang diatur dalam KUHAP dan prosedur pengajuannya yang tidak sederhana dan membutuhkan perjuangan dari korban tindak pidana sendiri untuk mendapatkan restitusi.

2) Pengajuan restitusi menggunakan proses yang diatur dalam UU No. 31 Tahun 2014 tentang Perlindungan Saski dan Korban, maka tidak semua korban tindak pidana dapat mengajukan restitusi, karena tidak semua tindak pidana dapat diterima oleh LPSK. Permasalahan lain yakni terkait eksekusi pelaksanaan restitusinya mengingat LPSK tidak termasuk dalam sistem peradilan pidana di Indonesia, serta bukan merupakan penegak hukum yang memiliki kewenangan untuk mengeksekusi restitusi. 


\section{Rumusan restitusi yang ideal dalam memberikan perlindungan hukum bagi korban tindak pidana.}

Perbuatan tindak pidana akan menimbulkan kerugian bagi korban, tidak hanya materi tetapi kerugian imateriil juga ditanggung oleh korban, dalam penjatuhan hukuman penjara kepada pelaku tindak pidana tidak ada hubungannya dengan korban, seakan akan dilupakan. Kerugian yang ditimbulkan atas perbuatan jahat yang dilakukan oleh para pelaku, aturan-aturan hukum sekarang memang kurang memperhatikan kepentingan para korban padahal dalam Kongres PBB VII tahun 1985 di Milan Italia tentang "The Prevention of Crime and The Treatment of Offenders" menyatakan bahwa "Victims right shold be perceived as an integral aspect of the total criminal justice sistem" Pada dasarnya manusia selalu mencari perlindungan dari ketidakseimbangan yang dialaminya, baik itu ketidakseimbangan hak-haknya maupun perilaku terhadapnya. Perlindungan itu dapat berupa perbuatan maupun aturan-aturan sehingga tercapai keseimbangan yang selaras dalam kehidupannya. (Muladi, 1995: 35)

Pemberian hak restitusi terdapat peraturan-peraturan yang berlaku antara lain, dalam Undang-Undang No. 13 tahun 2006 yang diperbaharui dengan Undang-Undang No. 31 Tahun 2014 tentang LPSK yang diharapkan untuk memberikan perlindungan khususnya terhadap saksi dan korban selama ini masih kurang dirasakan manfaatnya, dalam hukum acara di peradilan juga kurang dapat diimplementasikan. Dalam sistem peradilan pidana peran saksi dan korban dalam menuntut hak-haknya memerlukan pembuktian dalam mengungkap kebenaran materiil dan mendapatkan haknya. Bahwa dalam hukum acara pidana di Indonesia secara umum tidak terdapat aturan yang melindungi korban dalam perkara pidana, dibanding dengan perlindungan terhadap tersangka maupun terdakwa padahal kedudukan korban dan pelaku adalah sama dan hak korban yang dirampas atau ditimbulkan oleh pelaku sepantasnya korban mendapatkan apa yang sudah hilang darinya. Undang-Undang No. 31 tahun 2014 tentang perlindungan saksi dan korban masih memiliki banyak kekurangan yaitu belum direvisinya peraturan pelaksananya yaitu PP No. 44 tahun 2008 Pemberian Kompensasi, Restitusi dan bantuan yang merupakan aturan teknis agar implementasi restitusi dapat berjalan dengan efektif.

Bahwa pemberlakuan restitusi dalam berbagai peraturan di Indonesia seperti Undang-Undang KUHAP, Undang- Undang LPSK, Undang-Undang Tindak Pidana Perdagangan Orang dan lainnya cenderung menggunakan pendekatan monetary remedis. Banyak kekurangan dalam peraturan-peraturan yang mengatur restitusi dimulai dari 
ketentuan KUHAP. Suatu pemidanaan dirasa bermanfaat terhadap korban tindak pidana yang sifatnya individual adalah dengan terbalasnya dendam dan kepuasan batin korban tetapi juga kerugian riil yang diderita korban juga seharusnya men jadi perhatian penting yaitu dengan ganti kerugian atau restitusi. Bagi masyarakat luas kemanfaatan penjatuhan pemidanaan dirasa ada apabila secara relatif masyarakat merasakan ketentraman, perlindungan, keadilan dan lain sebagainya.

Kekurangan pengaturan restitusi karena dapat memakan waktu lama dan tinggi biayanya. Sehingga kerap kali menimbulkan kesulitan bagi mereka yang tidak mampu material, finansial. Cara penuntutan ganti kerugian melalui peradilan perdata akhirnya tidak akan menguntungkan bagi korban yang tidak mampu finansial. Sedangkan mereka inilah yang paling memerlukan bantuan setelah mengalami musibah, menjadi korban (mental, fisik, dan sosial). Dengan kata lain gugatan ini hanya bisa diajukan melalui gugatan perkara perdata. (R.Soeparmono, 2003:67) Lagipula bagaimana seorang korban perkosaan yang sangat menderita secara fisik dan psikologis masih dapat berfikir untuk melakukan tuntutan ganti kerugian kepada pelaku. Bahkan untuk mengingat pelaku dan perbuatannya sudah menambah penderitaannya. Putusan hakim hanya terbatas tentang pengabulan yang menetapkan penggantian biaya yang telah dikeluarkan oleh pihak yang dirugikan. Hal ini berarti besarnya ganti kerugian hanyalah sebesar jumlah kerugian nyata atau kerugian materiil saja. diluar kerugian nyata, seperti kerugian yang bersifat immaterial tidak dapat diajukan dalam perkara. Seandainya ganti kerugian immaterial diajukan oleh pihak yang dirugikan hakim harus menyatakan gugatan tersebut tidak dapat diterima (niet onvankelijke). Ganti kerugian pada dasarnya meliputi kerugian material dan immaterial. Namun demikian dilihat dari ketentuan tersebut di atas yang dimaksud dengan ganti rugi adalah ganti rugi yang bersifat material. Apabila dikaitkan dengan pasal 99 ayat (2) KUHAP yakni hanya berupa biaya yang dikeluarkan oleh pihak yang dirugikan sehingga tuntutan yang lain harus dinyatakan tidak diterima, dan harus diajukan dengan gugatan perdata biasa. Gugatan perkara perdata tersebut tidak merupakan perkara "ne bis in idem". Tujuan penggabungan gugatan ganti rugi ini adalah menyederhanakan proses perkara perdata yang timbul dari tindak pidana. Namun kerugian yang ditimbulkan hanya terbatas pada kerugian materiil saja, yaitu penggantian biaya yang telah dikeluarkan si korban, tidak mencakup pada penggantian kerugian immaterial. Bila korban ingin mengajukan ganti rugi atas kerugian immateriil yang dialaminya, maka korban harus mengajukan gugatan perdata biasa yang kita ketahui 
bahwa mempunyai prosedur yang panjang. Tidaklah mudah bagi korban perkosaan yang menderita dan mengalami trauma berfikir untuk mengajukan Hal ini sama sekali tidak memberikan perlindungan bagi korban tindak pidana perkosaan, bahwa korban tindak pidana perkosaan sangat dirugikan baik secara materiil terutama secara immaterial, ini berarti bahwa korban tidak bisa memperoleh ganti rugi atas kerugian immaterial yang dialaminya. (Lilik Mulyadi, 2008: 264) Menurut Soeparmono sistem dan lembaga penggabungan perkara gugatan ganti kerugian tersebut dalam pasal-pasalnya dalam KUHAP belumlah memuaskan. Adapun alasan-alasannya adalah seperti dibawah ini dan merupakan kelemahan dari KUHAP:

1) Sistem penggabungan tersebut dirasakan belum mendekati hakekat tujuan ganti kerugian itu sendiri;

2) Tuntutan ganti kerugian oleh orang lain yang menderita langsung kerugian atau pihak korban untuk memperoleh jumlah besarnya ganti kerugian "dibatasi" hanya pada kerugian meteriil yang nyata-nyata dikeluarkan oleh orang yang dirugikan langsung tersebut.

3) Untuk kerugian non-materiil, yaitu kerugian immateriil terpaksa harus mengajukan lagi dengan gugatan perkara biasa tersendiri, yang mungkin dapat memakan waktu lama;

4) Menurut M.Yahya Harahap, "Pembahasan Permasalahan dan penerapan KUHAP, jilid II, Bab penggabungan perkara gugatan ganti kerugian” dikatakan: kondisi seperti ini berarti sedikit banyak mengaburkan kembali maksud semula dari penggabungan itu sendiri, yang bertujuan untuk menyederhanakan proses dan biaya ringan.

Adanya kendala dalam pelaksanaan masalah pembayaran ganti kerugian tersebut. Apabila pihak korban tetap menuntut ganti kerugian yang bersifat immateriil juga, hasilnya akan nihil, karena putusan selalu menyatakan: gugatan ganti kerugian immateriil tersebut dinayatakan tidak dapat diterima, kerena tidak berdasarkan hukum, Karena gugatan ganti kerugian pada perkara pidana hanya bersifat assessor. (R.Soeparmono, 2003:67) Kepentingan korban dalam penyelesaian perkara pada sistem peradilan pidana juga mempunyai aspek negatif. Dikatakan demikian karena melalui optik KUHAP perlindungan korban ternyata dibatasi, relatif kurang sempurna dan kurang memadai. Konkretnya, korban belum mendapat perhatian secara proporsional atau perlindungan korban lebih banyak merupakan perlindungan tidak langsung. Aspek ini implisit melalui 
ketentuan Pasal 100 ayat (2) KUHAP yang berbunyi sebagai berikut.. Pasal 100 ayat (2) KUHAP “Apabila dalam suatu perkara pidana yang tidak diajukan permintaan banding, maka ganti rugi tidak diperkenankan”.

Menurut Muladi, dalam rangka konsep pengaturan terhadap perlindungan korban tindak pidana, hal pertama yang harus diperhatikan yakni esensi kerugian yang diderita korban. Esensi kerugian tersebut tidak hanya bersifat material atau penderitaan fisik saja tetapi juga yang bersifat psikologis. Hal ini dalam bentuk "trauma kehilangan kepercayaan terhadap masyarakat dan ketertiban umum”. Simptom dari sindrom tersebut dapat berupa kegelisahan, rasa curiga, sinisme, depresi, kesepian dan perilaku penghindaran lainnya. (Muladi, 2002: 177)

Salah satu bentuk ganti rugi terhadap korban tindak pidana yakni restitusi. Restitusi sesuai dengan prinsip pemulihan dalam keadaan semula (restutio in integrum) adalah suatu upaya bahwa korban kejahatan haruslah dikembalikan pada kondisi semula sebelum kejahatan terjadi meski didasari bahwa tidak akan mungkin korban kembali pada kondisi semula. Prinsip ini menegaskan bahwa bentuk pemulihan kepada korban haruslah selengkap mungkin dan mencakup berbagai aspek yang ditimbulkan dari akibat kejahatan. Dengan restitusi, maka korban dapat dipulihkan kebebasan, hak-hak hukum, status sosial, kehidupan keluarga dan kewarganegaraan, kembali ke tempat tinggalnya, pemulihan pekerjaannya, serta dipulihkan asetnya. Dalam praktik hampir di banyak negara konsep restitusi ini dikembangkan dan diberikan pula kepada korban kejahatan atas penderitaan mereka sebagai korban tindak pidana. Dalam konsep ini maka korban dan keluarganya harus mendapatkan ganti kerugian yang adil dan tepat dari orang bersalah atau pihak ketiga yang bertanggungjawab. Ganti kerugian ini akan mencakup pengembalian harta milik atau pembayaran atas kerusakan atau kerugian yang diderita, penggantian biaya-biaya yang timbul sebagai akibat jatuhnya korban, penyediaan jasa dan hak-hak pemulihan. (Supriyadi Widodo Eddyono: 16)

Akan tetapi, aturan yang spesifik tentang restitusi yang baru diatur di dalam PP No. 44 Tahun 2008 ternyata menimbulkan masalah dalam praktiknya. Banyak hakim dan jaksa yang cenderung lebih memilih menggunakan penggabungan gugatan ganti kerugian sebagaimana diatur dalam Pasal 98 KUHAP karena hukum acaranya dianggap lebih pasti, kuat, dan fleksibel daripada mekanisme restitusi dalam UU No. 13 Tahun 2006 yang justru dijabarkan dalam PP No. 44 Tahun 2008. Banyak aparat penegak hukum yang menganggap pengaturan mekanisme restitusi di dalam PP No. 44 Tahun 2008 
tersebut tidak sejajar dengan pengaturan dalam KUHAP sehingga pemberian Restitusi bagi Korban Tindak pidana, memiliki kekuatan sebagaimana berada di bawah KUHAP. Oleh karena itu, mekanisme restitusi yang seharusnya digunakan yakni mekanisme yang diatur oleh Pasal 98 KUHAP.

Soerjono Soekanto menyatakan bahwa masalah pokok penegakan hukum sebenarnya terletak pada berbagai faktor yang mungkin akan memepengaruhinya dan faktor tersebut mempunyai arti yang netral sehingga dampak posistif atau negatifnya terletak pada isi faktor tersebut. Faktor faktor tersebut adalah sebagai berikut : faktor hukumnya sendiri, faktor penegak hukum, faktor sarana atau fasilitas, faktor masyarakat dan yg terakhir faktor kebudayaan yakni sebagai hasil karya cipta rasa karsa manusia. (Soerjono Soekanto, Sri Mamudji, 2006: 5)

Kepastian hukum dan keadilan seringkali menjadi permasalahan dalam perkara pidana. Demikian pula dengan masalah keadilan yang juga harus diberikan kepada korban tindak pidana. Sehubungan dengan hal ini menarik untuk disimak pendapat Soenarjati Hartono bahwa kaidah hukum bukanlah merupakan tujuan, melainkan hanyalah jembatan yang akan membawa kita pada ide yang dicita-citakan. Tujuan hukum yang terpenting adalah untuk mencapai keadilan di dalam masyarakat. (Antonius Sudirman, 2007:27) Pemberian restitusi dalam Undang-Undang Tindak Pidana Perdagangan Orang yang menjelaskan mekanisme dalam menuntut hak restitusi yang dimulai dengan melaporkan tindak pidana kemudian pihak kepolisian wajib memberitahukan bahwa korban tindak pidana mempunyai hak restitusi dalam memberikan ganti rugi terhadap hak-hak yang terampas oleh tersangka, dan meminta bantuan penyidik kepolisian untuk menghitung kerugian tindak pidana dan kepolisian wajib memasukan permohonan ganti rugi/restitusi kedalam BAP (Berita Acara Pemeriksaan) kemudian tersangka oleh penyidik wajib menanyakan jumlah kekayaan baik harta dan benda tersangka. kepolisian berkas tersebut dilimpahkan ke Kejaksaan kemudian Jaksa Penuntut Umum wajib menerima permohonan restitusi, memeriksa dan menghitung jumlah kerugian yang dialami korban baik secara materiil maupun imateriil. Penuntut Umum harus berperan mewakili korban tindak pidana dalam menuntut hak kerugian di Pengadilan, Pengadilan juga harus menerima tuntutan restitusi tersebut dan menetapkan nilai kerugian yang harus dibayarkan kepada korban dan memberikan kewenangan kepada JPU untuk mengesekusi pemberian restitusi dengan cara terlebih dahulu menyita harta benda milik pelaku tindak pidana sebagai jaminan agar pemberian 
restitusi dapat mendapatkan kepastian. Kemudian apabila pelaku tindak pidana tidak mempunyai harta benda sehingga tidak mampu membayar restitusi maka dapat dikenakan pidana tambahan berupa kurungan penjara tetapi dengan jangka waktu yang setimpal sehingga pelaku mendapatkan efek jera. Dalam hukum pidana dikenal adagium "Niminem Laedere" dan "Suum Cuique ribuere" keduanya saling berkaitan. Adagium pertama mengandung arti "jangan merugikan orang lain". Sedang yang ke dua mengandung arti " memberikan setimpal dengan salah/jasa/perbuatannya". Bila kedua adagium tersebut dirangkaikan maka dapat diartikan " siapa saja yang merugikan orang lain, akan diganjar dengan hukuman yang setimpal atau sebanding dengan hukuman. (Barda Nawawi Arief, 2007 :61)

\section{Simpulan}

Pemberian restitusi masih belum tercapai disebabkan kelemahan yang berhubungan dengan peraturan perundang-undangan. Hal ini dapat dilihat dari adanya peraturan perundang-undangan yang mengatur mekanisme terkait restitusi kepada korban tindak pidana yang kurang memberikan kepastian hukum serta tidak seragamnya pengaturan pemberian restitusi, seharusnya diselaraskan antar peraturan-peraturan yang terkait restitusi. Para korban tindak pidana belum tentu mendapatkan hak ganti rugi aturan pemberian restitusi hanya melingkupi korban tindak pidana tertentu. Dalam hal tersebut membuat penegak hukum cenderung memilih menggunakan Kitab Undang- Undang Hukum Acara Pidana karena aturan hukumnya dianggap lebih pasti dan efektif. Bentuk pemberian ganti rugi selama ini masih bersifat sebatas kerugian materiil padahal korban juga menderita kerugian secara fisik maupun psikis. Oleh karena itu diperlukan konsep dan perhitungan kerugian imateriil terhadap korban.

Rumusan untuk pengaturan restitusi kedepan hal pertama yang harus diperhatikan adalah esensi kerugian yang selama ini hanya sifatnya materiil yaitu kerugian yang nyata dialami korban dengan bukti-bukti tetapi penting juga memperhartikan kerugian korban yang sifatnya imateriil yang sifatnya kerugian fisik maupun psikologis. Pemberian restitusi terdapat dua model yaitu model prosedural (the prosedural right model) dan model pelayanan (the service model) untuk perumusan restitusi yang ideal yaitu menggunakan model pelayanan dimana korban diberikan pelayanan oleh penuntut umum guna mewakili tuntutan ganti rugi korban sehingga dapat menghemat biaya dan meringankan beban penderitaan korban tindak pidana. 


\section{E. Saran}

1) Pemerintah perlu memberikan pengaturan khusus terkait restitusi melalui lembaga legislatif agar semua korban tindak pidana diharapkan mendapat kepastian hukum dengan disertai mekanisme pelaksanaan yang jelas.

2) Para penegak hukum khususnya kepada penuntut umum hendaknya ikut berperan untuk lebih memperhatikan hak korban tindak pidana dengan model pelayanan sehingga korban tidak harus bersusah payah dan menghabiskan biaya untuk mendapatkan ganti rugi.

\section{F. Daftar Pustaka}

Antonius Sudirman. 2007. Hati Nurani Hakim dan Putusannya. Bandung: PT. Citra Aditya Bakti.

Andika Wijaya dan Dida Peace Ananta. 2016. Darurat Kejahatan Seksual. Jakarta: Sinar Grafika.

Barda Nawawi Arief. 2007. Masalah Penegakan Hukum dan kebijakan Hukum Pidana dalam Penanggulangan Kejahatan. Jakarta: Kencana.

Bambang Wahyu. 2014. Viktimologi Perlindungan korban dan Saksi. Jakarta: Sinar Grafika.

Darji Darmodiharjo dalam Muhamad Erwin. 2012. Filsafat Hukum Refleksi. Kritis Terhadap Hukum. Jakarta: PT. Rajagrafindo Persada.

Jeremy Bentham. 2006. Teori Perundang-Undangan Prinsip-Prinsip Legislasi, Hukum Perdata dan Hukum Pidana. Bandung: Penerbit Nusamedia \& Penerbit Nuansa.

Lilik Mulyadi. 2008. Hukum Acara Perdata Menurut Teori dan Praktik Peradilan Indonesia. Jakarta: Djambatan.

Muladi. 1995. Kapita Selekta Sistem Peradilan Pidana. Semarang: Badan Penerbit Undip.

Marlina dan Azmiati Zuliah. 2015. Hak Restitusi Terhadap Korban Tindak Pidana Perdagangan Orang. Bandung: Refika Aditama.

M. Yahya Harahap.2008. Pembahasan Permasalahan Dan Penerapan KUHAP (Pemerikasaan Sidang Pengadilan Banding, Kasasi, dan Peninjauan Kembali). Jilid II. Jakarta: Sinar Grafika.

Muladi. 1995. Kapita Selekta Sistem Peradilan Pidana. Semarang: Badan Penerbit Undip. 
Muladi. 2002. "Hak Asasi Manusia, Politik dan Sistem Peradilan Pidana". Semarang: Badan Penerbit Universitas Diponegoro.

R.Soeparmono. 2003. Praperadilan dan Penggabungan Perkara Gugatan Ganti Kerugian Dalam KUHAP. Bandung: Mandar Maju,

Soerjono Soekanto dan Sri Mamudji. 2006. Penelitian Hukum Normatif, Suatu Tinjauan Singkat. Jakarta: PT. Raja Grafindo Persada.

UNODC. Handbook on Restorative Justice Programmes. CrimKinal Justice Handbook Series. (Vienna: UN New York. 2006).

Abdul Haris Samendawai. 2009. Hak-Hak Korban Pelanggaran HAM Yang Berat (Tinjauan Hukum Internasional dan Nasional). Jurnal Hukum. Vol. No. 2

Dheny Wahyudhi.. 2015. Perlindungan Terhadap Anak yang Berhadapan Dengan Hukum Melalui Pendekatan Restorative Justice. Jurnal Ilmu Hukum.

Alvianto. R.V. Ransun. 2012. Mekanisme Pemberian Kompensasi dan Restitusi Bagi Korban Tindak Pidana. Jurnal Lex Crimen Vol. I. Manado: Fakultas Hukum Universitas Sam Ratulangi.

Setyo Utomo. Sistem Pemidanaan Dalam Hukum Pidana Yang Berbasis Restorative Justice. Jurnal Mimbar Justitia. Vol. V No. 01. Cianjur: Fakultas Hukum Universitas Suryakancana.

Supriyadi Widodo Eddyono. et.al, Makalah, "Masukan Terhadap Perubahan UU No. 13 Tahun 2006 tentang Perlindungan Saksi dan Korban”. Jakarta: Koalisi Perlindungan Saksi dan Korban.

RUU tentang Kitab Undang-Undang Hukum Pidana, Direktorat Perundang-Undangan, Dirjen Hukum dan Perundang-Undangan, departemen dan Perundang-undangan. 1999-2000.

www.hukumonline.com, Model Perlindungan Saksi dan Korban Tergantung Anggota LPSK, 5 September 2017. 